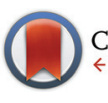

CrossMark $\leftarrow$ click for updates

Cite this: Dalton Trans., 2016, 45 11892

Received 22nd May 2016, Accepted 30th June 2016

DOI: $10.1039 / c 6 d t 02046 a$

www.rsc.org/dalton

\title{
Tris-ureas as transmembrane anion transporters $\uparrow$
}

\author{
Martina Olivari, ${ }^{a}$ Riccardo Montis, ${ }^{a}$ Stuart N. Berry, ${ }^{b}$ Louise E. Karagiannidis, ${ }^{b}$ \\ Simon J. Coles, ${ }^{b}$ Peter N. Horton, ${ }^{b}$ Lucy K. Mapp, ${ }^{b}$ Philip A. Gale ${ }^{* b}$ and \\ Claudia Caltagirone*a
}

\begin{abstract}
Nine tris-urea receptors $\left(\mathbf{L}^{1}-\mathbf{L}^{9}\right)$ have been synthesised and shown to coordinate to a range of anionic guests both by ${ }^{1} \mathrm{H}$ NMR titration techniques and single crystal $\mathrm{X}$-ray structural analysis. The compounds have been shown to be capable of mediating the exchange of chloride and nitrate and also chloride and bicarbonate across POPC or POPC : cholesterol 7:3 vesicle bilayer membranes at low transporter loadings. An interesting dependency of anion transport on the nature of the cation is evidence to suggest that a $\mathrm{M}^{+} / \mathrm{Cl}^{-}$cotransport process may also contribute to the release of chloride from the vesicles.
\end{abstract}

\section{Introduction}

Transmembrane transport of anions across lipid bilayers is an important biological process that is normally regulated by complex membrane spanning proteins. A range of diseases, known as "channelopathies", including cystic fibrosis, are caused by malfunctioning ion channels. ${ }^{1}$ There is currently interest in the design of synthetic membrane transporters for anions that can act as potential future therapeutic substitutes for these malfunctioning proteins and have other biological applications. $^{2-4}$

Gale and co-workers have recently described the anion binding properties of a series of ortho-phenylenediaminebased bis-ureas. ${ }^{5,6}$ These compounds are highly effective anion transporters that function by an anion antiport, and in some cases a HCl symport carrier mechanism. Addition of electronwithdrawing groups to either the central core or the peripheral phenyl groups improved the anion transport ability: the transporter activity increased with the electron withdrawing strength of the substituent with the trend $\mathrm{H}<\mathrm{F} \approx \mathrm{Cl}<\mathrm{CF}_{3}<$ $\mathrm{CN}<\mathrm{NO}_{2}$. Indeed, the $p$-nitro functionalised compound was shown to possess a very high transport activity, facilitating chloride efflux at concentrations as low as 1:1000 000 transporter to lipid molar ratio.

${ }^{a}$ Dipartimento di Scienze Chimiche e Geologiche, Università degli Studi di Cagliari, S.S. 554 Bivio per Sestu, 09042 Monserrato (CA), Italy.E-mail: ccaltagirone@unica.it ${ }^{b}$ Chemistry, University of Southampton, Southampton, SO17 1BJ, UK. E-mail: philip.gale@soton.ac.uk

$\dagger$ Electronic supplementary information (ESI) available: Additional information as noted in the text including synthetic details for the preparation of $\mathbf{L}^{1}-\mathbf{L}^{9}$, fittings of ${ }^{1} \mathrm{H}-\mathrm{NMR}$ titrations, crystallographic tables, transport studies. CCDC 1481148-1481150 for $\left[\mathbf{L}^{5}\left(\mathrm{Cl}^{-}\right)\right]\left(\mathrm{TBA}^{+}\right),\left[\mathbf{L}^{\mathbf{4}}\left(\mathrm{Cl}^{-}\right)_{2}\right]\left(\mathrm{TBA}^{+}\right)_{2},\left[\mathbf{L}^{5}\left(\mathrm{AcO}^{-}\right)\right]\left(\mathrm{TBA}^{+}\right)$. For ESI and crystallographic data in CIF or other electronic format see DOI: 10.1039/c6dt02046a
Gale et al. have also reported the transmembrane anion transport of phosphoric triamide and thiophosphoric triamide-based receptors, ${ }^{7}$ and tris-urea tripodal receptors. ${ }^{8-10}$

Tris-urea receptors can be divided in two main families: tripodal receptors based on flexible linkers such as TREN (tris(2-aminoethyl)amine) that are able to preferentially bind oxoanions ${ }^{5,11-19}$ and to work as organogelators, ${ }^{20}$ or rigid spacers such as cyanuric acid, ${ }^{21}$ benzene, ${ }^{22}$ or trindane. ${ }^{23}$

Recently $\mathrm{Wu}$ and co-workers designed and synthesised a new family of tris-ureas ${ }^{24,25}$ and tris-thioureas ${ }^{26}$ developed mimicking the scaffold of terpyridine as efficient receptors for phosphate and sulfate. Starting from the interesting results obtained by Gale with the ortho-phenylenediamine-based bisureas transporters we decided to expand the family of tris-ureas reported by $\mathrm{Wu}$ and therefore we synthesised nine receptors $\left(\mathbf{L}^{1}-\mathbf{L}^{9}\right.$ in Scheme 1). We investigated the anion binding properties both in solution and in the solid state of the nine receptors and their ability to transport anions across lipid bilayers.
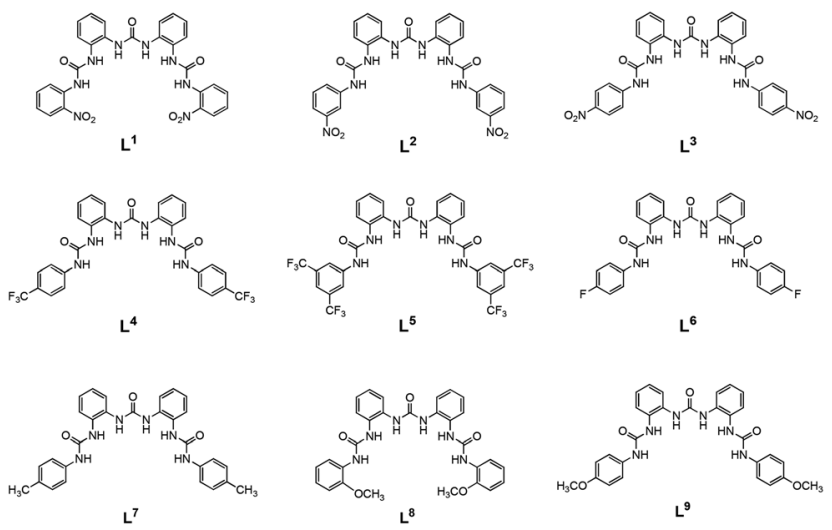

Scheme 1 Representation of receptors $L^{1}-L^{9}$. Receptor $L^{3}$ has already been published. ${ }^{25}$ 


\section{Results and discussion}

The synthesis of receptor $\mathbf{L}^{3}$ has previously been reported by Wu. ${ }^{25} \mathbf{L}^{\mathbf{1}}-\mathbf{L}^{\mathbf{9}}$ were synthesized via different reaction steps. Firstly 1,3-bis(2-aminophenyl)urea was prepared by reaction of ortho-phenylenediamine with ortho-nitro-phenylisocyanate in a mixed solvent $\mathrm{THF} /$ toluene at $0{ }^{\circ} \mathrm{C}$ and subsequent reduction of the 1-(2-nitrophenyl)-3-(2-aminophenyl)urea obtained by hydrazine and $\mathrm{Pd} / \mathrm{C}$ 10\%. 1,3-Bis(2-aminophenyl)urea was the reacted with the appropriate isocyanate (4-(trifluoromethyl) phenyl isocyanate; 3,5-bis(trifluoromethyl)phenyl isocyanate; 4-fluorophenyl isocyanate; $p$-tolyl isocyanate; 2-methoxyphenyl isocyanate; 4-methoxyphenyl isocyanate) in refluxing dichloromethane (DCM) under a $\mathrm{N}_{2}$ atmosphere to obtain $\mathbf{L}^{\mathbf{1}}-\mathbf{L}^{\mathbf{9}}$ in 60-90\% yield (see ESI $\uparrow$ for synthetic details).

Anion-binding studies were performed by means of ${ }^{1} \mathrm{H}-\mathrm{NMR}$ titrations in DMSO- $d_{6}$. Stability constants from the ${ }^{1} \mathrm{H}$-NMR titration curves obtained (see ESI Fig. S1-S13 $\dagger$ ) were calculated by fitting the data to a $1: 1$ binding model using $\mathrm{EQNMR}^{27}$ as shown in Table 1.

Under the conditions of these experiments, the receptors did not interact with nitrate (i.e. no shift of the $\mathrm{NH}$ proton resonances occurred upon addition of tetrabutylammonium nitrate). Interestingly, receptors $\mathbf{L}^{\mathbf{1}}-\mathbf{L}^{\mathbf{3}}$ which contain nitro electron-withdrawing groups showed little interaction with chloride, while addition of bicarbonate caused the disappearance of the signals attributed to the urea $\mathrm{NH}$ groups, evidence in support of a deprotonation or exchange process. Receptor $\mathbf{L}^{\mathbf{4}}$, bearing one $\mathrm{CF}_{3}$ substituent on the peripheral phenyl ring showed some affinity for chloride. On the other hand, receptors $\mathbf{L}^{\mathbf{6}}, \mathbf{L}^{7}$, and $\mathbf{L}^{\mathbf{9}}$ were able to bind both chloride and bicarbonate with comparable stability constants, while $\mathbf{L}^{\mathbf{5}}$ and $\mathbf{L}^{\mathbf{8}}$ bound bicarbonate preferentially.

A series of crystallization experiments of receptors $\mathbf{L}^{\mathbf{1}}-\mathbf{L}^{\mathbf{9}}$ in presence of an excess of anions such as acetate, chloride, bicarbonate and nitrate were carried out with the aim of investigating the anion-binding properties of the receptors in the

Table 1 Association constants $\left(K_{\mathrm{a}} / \mathrm{M}^{-1}\right)$ for the formation of complexes of $\mathrm{L}^{1}-\mathrm{L}^{9}$ with anions added as tetrabutylammonium salts (or tetraethylammonium in the case of hydrogencarbonate) in DMSO- $d_{6}$ at $300 \mathrm{~K}$. All errors estimated to be $\leq 14 \%$ (see ESI)

\begin{tabular}{|c|c|c|c|}
\hline \multirow{2}{*}{ Receptors } & \multicolumn{3}{|c|}{ Anions } \\
\hline & $\mathrm{Cl}^{-}$ & $\mathrm{HCO}_{3}{ }^{-}$ & $\mathrm{NO}_{3}^{-}$ \\
\hline $\mathbf{L}^{1}$ & $<10$ & Deprotonation $^{a}$ & No interaction \\
\hline $\mathbf{L}^{2}$ & $<10$ & Deprotonation $^{a}$ & No interaction \\
\hline $\mathbf{L}^{3}$ & $<10$ & Deprotonation $^{a}$ & No interaction \\
\hline $\mathrm{L}^{4}$ & 262 & Deprotonation $^{a}$ & No interaction \\
\hline $\mathbf{L}^{5}$ & $<10$ & 226 & No interaction \\
\hline$L^{6}$ & 205 & 203 & No interaction \\
\hline $\mathbf{L}^{7}$ & 226 & 221 & No interaction \\
\hline $\mathbf{L}^{8}$ & 28 & 802 & No interaction \\
\hline $\mathbf{L}^{9}$ & 225 & 240 & No interaction \\
\hline
\end{tabular}

${ }^{a}$ The NHs signals disappeared after the addition of one equivalent of anion. solid state. In order to be consistent with solution studies, all the crystallization experiments were conducted in DMSO. However, (compatibly with the low solubility of receptors $\mathbf{L}^{\mathbf{1}}-\mathbf{L}^{\mathbf{9}}$ in common solvents) with the aim of investigating the possible influence of less polar solvents in the anion-binding process, other solvents (AcOEt, $\mathrm{MeOH}, \mathrm{EtOH}, \mathrm{THF}, \mathrm{MeNO}_{2}, \mathrm{MeCN}$ ) and mixture of solvents $\left(\mathrm{MeOH} / \mathrm{MeNO}_{2}\right.$ and $\left.\mathrm{THF} / \mathrm{DMF}\right)$ were employed. Details of the crystallization experiments are reported in ESI (Table S1 $\dagger$ ).

As shown in Table S1 (see ESI $\dagger$ ) only a limited number of crystallizations were successful in producing single crystals. In particular, for a total of sixty-six crystallization experiments, only seven gave samples suitable for X-ray investigation. Within these, three gave the crystal structure of the simple tetrabutylammonium salt and the remaining four resulted in crystal structures $\left[\mathbf{L}^{\mathbf{4}}\left(\mathrm{Cl}^{-}\right)_{2}\right]\left(\mathrm{TBA}^{+}\right)_{2} \mathbf{a},\left[\mathbf{L}^{\mathbf{4}}\left(\mathrm{Cl}^{-}\right)_{2}\right]\left(\mathrm{TBA}^{+}\right)_{2} \mathbf{b}$ (isostructures obtained from $\mathrm{MeOH} / \mathrm{MeNO}_{2}$ and $\mathrm{MeCN}$ respectively; for the structural description the code $\left[\mathbf{L}^{\mathbf{4}}\left(\mathrm{Cl}^{-}\right)_{2}\right]\left(\mathrm{TBA}^{+}\right)_{2}$ is used to identify both), $\left[\mathbf{L}^{\mathbf{5}}\left(\mathrm{Cl}^{-}\right)\right]\left(\mathrm{TBA}^{+}\right)$and $\left[\mathbf{L}^{\mathbf{5}}\left(\mathrm{AcO}^{-}\right)\right]\left(\mathrm{TBA}^{+}\right)$ (both obtained from DMSO).

In general, these results seem to be consistent with the low anion-binding affinity observed in solution studies (Table 1). This is particularly evident for receptors $\mathbf{L}^{\mathbf{1}}-\mathbf{L}^{\mathbf{3}}$, where the unsuccessful crystallization experiments agree with the negligible interactions observed in solution (Table 1). In the case of receptor $\mathbf{L}^{\mathbf{4}}$, though the compound unexpectedly forms a $1: 2\left[\mathbf{L}^{4}\left(\mathrm{Cl}^{-}\right)_{2}\right]\left(\mathrm{TBA}^{+}\right)_{2}$ complex, the affinity toward $\mathrm{Cl}^{-}$is confirmed. For the remaining receptors $\mathbf{L}^{5}-\mathbf{L}^{\mathbf{9}}$, only in the case of receptor $\mathbf{L}^{\mathbf{5}}$ it was possible to isolate single crystals of anion complexes with chloride and acetate (not investigated in solution).

$\left[\mathbf{L}^{\mathbf{4}}\left(\mathrm{Cl}^{-}\right)_{2}\right]\left(\mathrm{TBA}^{+}\right)_{2}$ crystallised in the triclinic crystal system (space group $P \overline{1}$ ) with an asymmetric unit consisting of one receptor $\mathbf{L}^{\mathbf{4}}$, two chloride anions and two tetrabutylammonium counterions, resulting in a $1: 2$ complex. $\mathbf{L}^{\mathbf{4}}$ adopts a closed conformation, with the urea NHs all oriented toward the centre of a pseudo-cavity. The three urea groups are slightly tilted to interact via $\mathrm{N}-\mathrm{H} \cdots \mathrm{Cl}$ hydrogen bonds $(\mathrm{N}-\mathrm{H} \cdots \mathrm{Cl}$ distances are in the range 2.36(2)-2.51(2) A, average $2.43 \AA$ ) with the two $\mathrm{Cl}^{-}$anions which respectively lie below (Cl1) and above (Cl2) the pseudo-cavity (Fig. 1a and b). In particular it is worth noticing that the shortest distances are observed for $\mathrm{Cl} 2$

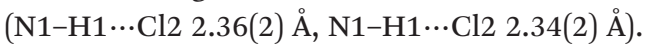

$\left[\mathbf{L}^{5}\left(\mathrm{Cl}^{-}\right)\right]\left(\mathrm{TBA}^{+}\right)$also adopts a triclinic crystal system (space group $P \overline{1})$. The asymmetric unit consists of one independent receptor $\mathbf{L}^{\mathbf{5}}$, one independent chloride and one independent tetrabutylammonium resulting in a $1: 1$ complex. Similarly to $\mathbf{L}^{\mathbf{4}}$ the receptor $\mathbf{L}^{\mathbf{5}}$ shows a closed conformation with the two peripheral urea NHs (Fig. 2a) pointing at the centre of the pseudo-cavity and interacting with the chloride via four $\mathrm{N}-$ $\mathrm{H} \cdots \mathrm{Cl}$ hydrogen bonds $(\mathrm{N}-\mathrm{H} \cdots \mathrm{Cl})$ distances are in the range 2.32(2)-2.75(3) A (average distance $2.53 \AA$ ). The central urea NHs are tilted to interact with an adjacent receptor-chloride unit via a second set of $\mathrm{N}-\mathrm{H} \cdots \mathrm{Cl}$ hydrogen bonds $(\mathrm{N}-\mathrm{H} \cdots \mathrm{Cl}$ distances are 2.44(3) ̊ and 2.74(3) ̊ respectively) forming a centrosymmetric dimer (Fig. 2b). 


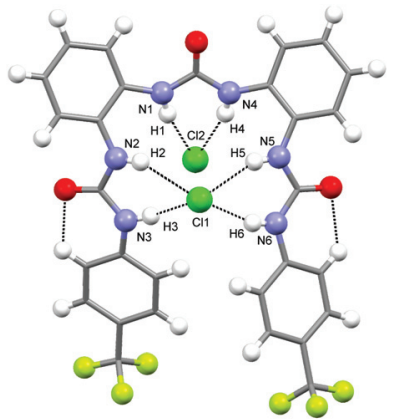

(a)

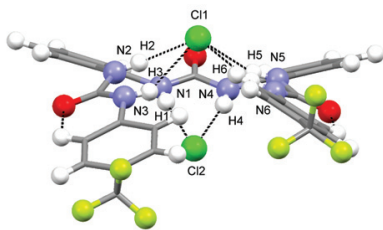

(b)
Fig. 1 Pseudo-cavity and main intermolecular interactions observed in structure $\mathrm{L}^{4} \mathrm{Cl}^{-}$, viewed along two orthogonal projections. TBA ${ }^{+}$counter cations are omitted for clarity. $\mathrm{N}-\mathrm{H} \cdots \mathrm{Cl}$ hydrogen bonds are indicated as black dashed lines.
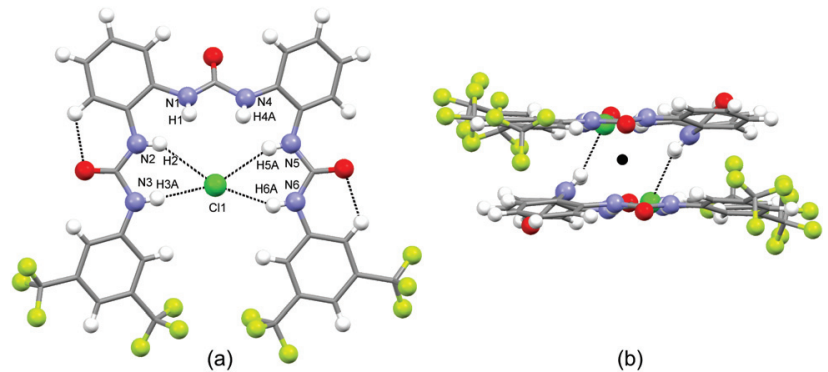

Fig. 2 Pseudo-cavity and main intermolecular interactions observed in structure $\left[\mathrm{L}^{5}\left(\mathrm{Cl}^{-}\right)\right]\left(\mathrm{TBA}^{+}\right)$, (a) $\mathrm{N}-\mathrm{H} \cdots \mathrm{Cl}$ hydrogen bonds involving peripheral ureas and $\mathrm{Cl}^{-}$. (b) $\mathrm{N}-\mathrm{H} \ldots \mathrm{Cl}$ hydrogen bonds involving central ureas and $\mathrm{Cl}^{-}$and centro-symmetric dimer. The molecules are oriented to best show the intermolecular interactions. $\mathrm{TBA}^{+}$counter cations and positional disorder in the $\mathrm{CF}_{3}$ groups are omitted for clarity. $\mathrm{N}-\mathrm{H} \cdots \mathrm{O}$ hydrogen bonds are indicated as black dashed lines, centre of inversion as black circle.

Similarly to the previous two structures, $\left[\mathbf{L}^{5}\left(\mathrm{AcO}^{-}\right)\right]\left(\mathrm{TBA}^{+}\right)$ crystallises in the triclinic crystal system (space group $P \overline{1}$ ). The asymmetric unit consists of one independent receptor $\mathbf{L}^{5}$, one independent acetate and one independent tetrabutylammonium. The receptor molecule adopts a closed conformation (Fig. 3a) to form a pseudo-cavity similar to those observed for $\left[\mathbf{L}^{4}\left(\mathrm{Cl}^{-}\right)_{2}\right]\left(\mathrm{TBA}^{+}\right)_{2}$ and $\left[\mathbf{L}^{5}\left(\mathrm{Cl}^{-}\right)\right]\left(\mathrm{TBA}^{+}\right)$. The peripheral NHs are oriented toward the centre of the pseudo-cavity interacting with the $\mathrm{AcO}^{-}$via $\mathrm{N}-\mathrm{H} \cdots \mathrm{O}$ hydrogen bonds $(\mathrm{N}-$

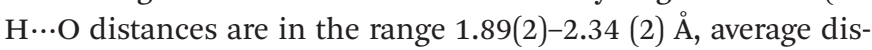
tance $2.13 \AA$ ). This is oriented perpendicularly to the plane of the pseudo-cavity and interacts via two $\mathrm{N}-\mathrm{H} \cdots \mathrm{O}$ hydrogen

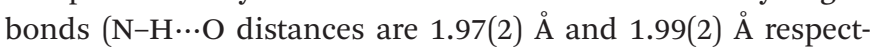
ively) with the central urea NHs of an adjacent receptor molecule (Fig. $3 \mathrm{~b}$ ) to form a centrosymmetric dimer similar to that observed for $\left[\mathbf{L}^{5}\left(\mathrm{Cl}^{-}\right)\right]\left(\mathrm{TBA}^{+}\right)$.

The anion transport properties of receptors $\mathbf{L}^{\mathbf{1}}-\mathbf{L}^{\mathbf{9}}$ were studied using vesicle-based methods. ${ }^{28}$ A sample of unilamellar POPC vesicles was prepared containing $489 \mathrm{mM} \mathrm{NaCl}$ buffered to $\mathrm{pH} 7.2$ with $5 \mathrm{mM}$ sodium phosphate salts. The

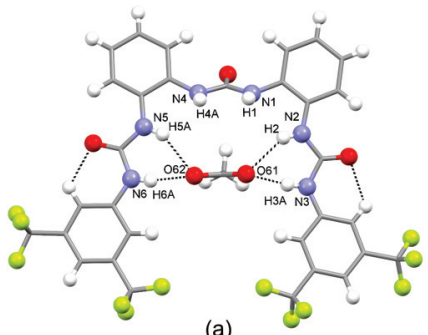

(a)

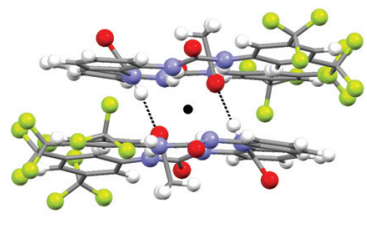

(b)
Fig. 3 Pseudo-cavity and main intermolecular interactions observed in structure $\left[\mathrm{L}^{5}\left(\mathrm{AcO}^{-}\right)\right]\left(\mathrm{TBA}^{+}\right)$; (a) $\mathrm{N}-\mathrm{H} \cdots \mathrm{O}$ hydrogen bonds involving peripheral ureas and $\mathrm{AcO}^{-}$. (b) $\mathrm{N}-\mathrm{H} \cdots \mathrm{O}$ hydrogen bonds involving central ureas and $\mathrm{AcO}^{-}$and centro-symmetric dimer. The molecules are oriented to best show the intermolecular interactions. TBA ${ }^{+}$counter cations are omitted for clarity. $\mathrm{N}-\mathrm{H} \cdots \mathrm{O}$ hydrogen bonds are indicated as black dashed lines, centre of inversion as black circle.

vesicles were suspended at a lipid concentration of $1 \mathrm{mM}$ in $489 \mathrm{mM} \mathrm{NaNO}_{3}$ buffered to $\mathrm{pH} 7.2$ with $5 \mathrm{mM}$ sodium phosphate salts.

A small amount of DMSO solution of the receptor $(0.02-2 \mathrm{~mol} \%$ with respect to lipid) was added to the vesicles suspension, and the resulting chloride efflux was monitored using a chloride ion selective electrode (ISE) for $300 \mathrm{~s}$. At the end of the experiment, the vesicles were lysed by the addition of detergent, and the final electrode reading was used to calibrate $100 \%$ chloride release. We found that all the compounds except $\mathbf{L}^{\mathbf{1}}$ (i.e. $\mathbf{L}^{2}-\mathbf{L}^{\mathbf{9}}$ ) (at $2 \mathrm{~mol} \%$ with respect to lipid) were capable of mediating chloride transport.

Under these experimental conditions the most active compounds are to be $\mathbf{L}^{2}, \mathbf{L}^{3}, \mathbf{L}^{4}$ and $\mathbf{L}^{6}$ (Fig. 4 and S14-S29 in ESI $\dagger$ ) In order to determine the mechanism of chloride release by receptors $\mathbf{L}^{2}-\mathbf{L}^{9}$, the transport assays were repeated suspending

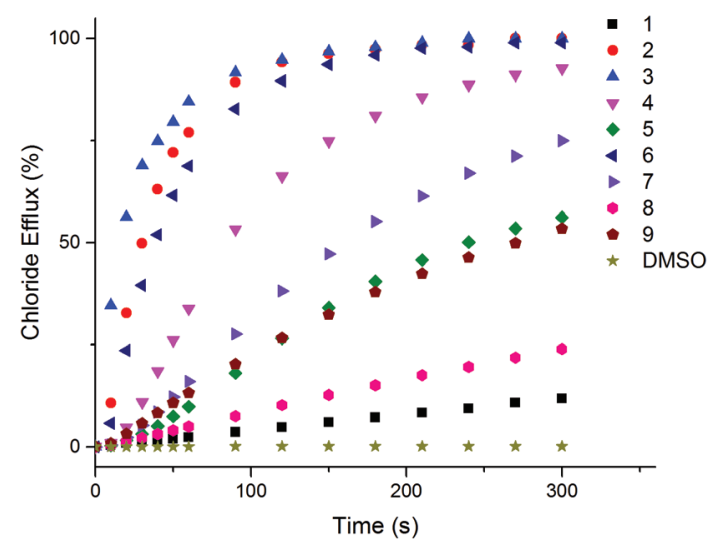

Fig. 4 Chloride efflux promoted by a DMSO solution of compounds $\mathrm{L}^{1}-\mathrm{L}^{9}$ (2 mol\% carrier to lipid) from unilamellar POPC vesicles loaded with $489 \mathrm{mM} \mathrm{NaCl}$ buffered to $\mathrm{pH} 7.2$ with $5 \mathrm{mM}$ sodium phosphate salts. The vesicles were dispersed in $489 \mathrm{mM} \mathrm{NaNO}_{3}$ buffered to $\mathrm{pH} 7.2$ with $5 \mathrm{mM}$ sodium phosphate salts. At the end of the experiment detergent was added to lyse the vesicles and calibrate the ISE to $100 \%$ chloride efflux. Each point represents an average of three trials. DMSO was used as a control. 
POPC vesicles loaded with $\mathrm{NaCl}(451 \mathrm{mM}$ with $20 \mathrm{mM}$ phosphate buffer at $\mathrm{pH} 7.2)$ in a solution of $\mathrm{Na}_{2} \mathrm{SO}_{4}(150 \mathrm{mM}$ with $20 \mathrm{mM}$ phosphate buffer at $\mathrm{pH}$ 7.2). DMSO suspensions of compounds $\mathbf{L}^{2}-\mathbf{L}^{9}$ were then added to the suspension. Usually during this experiment the antiport mechanism $\left(2 \mathrm{Cl}^{-} / \mathrm{SO}_{4}{ }^{2-}\right.$ exchange) would not be expected to be observed due to the high hydrophilicity of the $\mathrm{SO}_{4}{ }^{2-}$ anion ${ }^{29}$ which would inhibit the chloride efflux from the liposomes. ${ }^{9}$ However, as shown in Fig. 5, during the first two minutes of the experiment significant chloride release was observed for compounds $\mathbf{L}^{3}, \mathbf{L}^{2}$ and $\mathbf{L}^{\mathbf{6}}$. There is also some chloride efflux mediated by the other compounds except for $\mathbf{L}^{\mathbf{4}}$ and $\mathbf{L}^{\mathbf{5}}$ under these conditions. After $120 \mathrm{~s}$, a pulse of $\mathrm{NaHCO}_{3}$ solution was added, and we observed an increase of chloride efflux (Fig. 5 and S31-S46 in ESI†), evidence in support of a chloride/bicarbonate exchange process.

A lucigenin assay for chloride/sulfate exchange was run with compounds $\mathbf{L}^{\mathbf{2}}-\mathbf{L}^{\mathbf{9}}$ which showed that these compounds do not mediate sulfate transport (see ESI, Fig. S56† in the case of $\mathbf{L}^{6}$, as a representative compound). ${ }^{10}$

Although it has been recently reported that ureas and thioureas can facilitate proton or hydroxide transport, ${ }^{30}$ a HPTS assay to test for $\mathrm{H}^{+} / \mathrm{Cl}^{-}$co-transport resulted in inconclusive results for the class of molecules presented herein (see ESI, Fig. S57† in the case of $\mathbf{L}^{\mathbf{6}}$ as a representative compound).

To further examine the origin of the chloride transport during the first two minutes of this assay, we examined the possibility of a mechanism involving sodium/chloride cotransport. The $\mathrm{Cl}^{-} / \mathrm{NO}_{3}{ }^{-}$transport assays were repeated using vesicles containing caesium chloride (489 $\mathrm{mM} \mathrm{NaCl}$ buffered to $\mathrm{pH} 7.2$ with $5 \mathrm{mM}$ sodium phosphate salts) instead of sodium chloride, suspended in an isotonic sodium nitrate solution. In the event of $\mathrm{NaCl}$ co-transport we would expect the

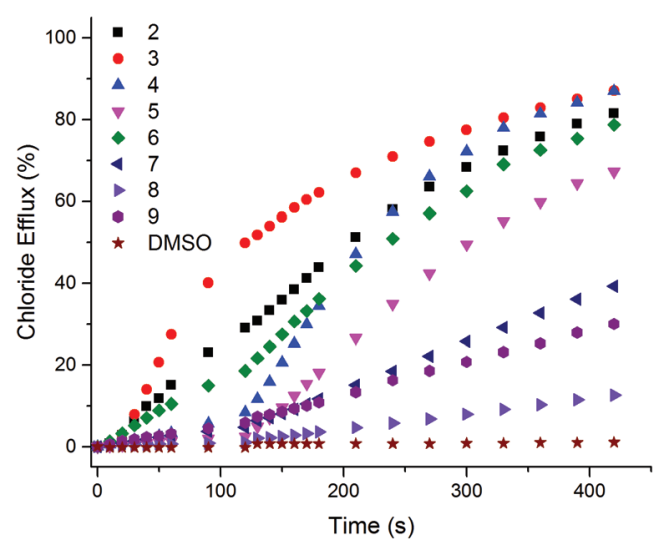

Fig. 5 Chloride efflux promoted by a DMSO solution of compounds $L^{2}-L^{9}$ (2 mol\% carrier to lipid) from unilamellar POPC vesicles loaded with $451 \mathrm{mM} \mathrm{NaCl}$ buffered to $\mathrm{pH} 7.2$ with $20 \mathrm{mM}$ sodium phosphate salts. The vesicles were dispersed in $150 \mathrm{mM} \mathrm{Na}_{2} \mathrm{SO}_{4}$ buffered to $\mathrm{pH} 7.2$ with $20 \mathrm{mM}$ sodium phosphate salts. At $t=120 \mathrm{~s}$ a solution of sodium bicarbonate was added such that the external concentration of bicarbonate was $40 \mathrm{mM}$. At the end of the experiment, detergent was added to lyse the vesicles and calibrate the ISE to $100 \%$ chloride efflux. Each point represents an average of three trials. DMSO was used as a control.

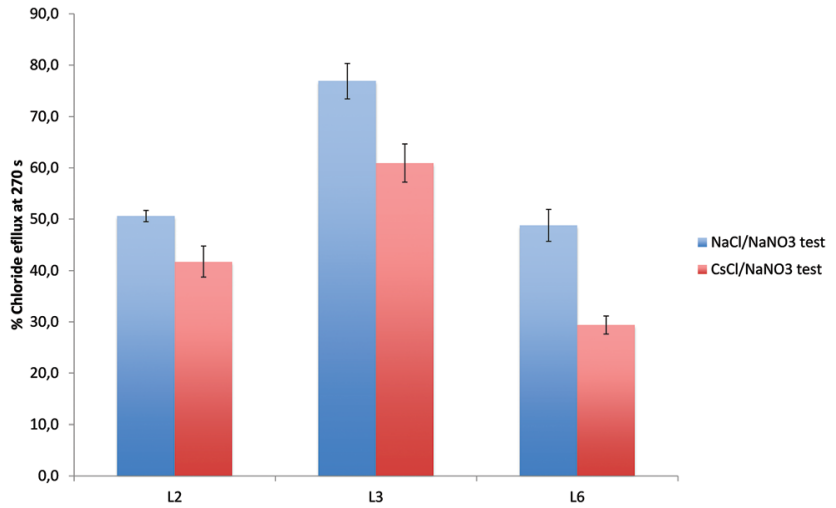

Fig. 6 Percentage chloride efflux at $270 \mathrm{~s}$ mediated by $\mathrm{L}^{2}, \mathrm{~L}^{3}$, and $\mathrm{L}^{6}$ (0.1 mol\% carrier to lipid) from unilamellar POPC vesicles loaded with either $489 \mathrm{mM} \mathrm{NaCl}$ (red) or $489 \mathrm{mM} \mathrm{CsCl}$ (blue) buffered to $\mathrm{pH} 7.2$ with $5 \mathrm{mM}$ sodium phosphate salts. The vesicles were dispersed in $489 \mathrm{mM}$ $\mathrm{NaNO}_{3}$ buffered to $\mathrm{pH} 7.2$ with $5 \mathrm{mM}$ sodium phosphate salts.

rate of chloride release to be different in the presence of $\mathrm{CsCl}$. As shown in Fig. 6 in the case of $\mathbf{L}^{2}, \mathbf{L}^{3}$, and $\mathbf{L}^{6}$ (and Fig. S47S55 in the ESI $\dagger$ ) the release of chloride is dependent on the nature of metal cation and it is reduced when the internal solution was replaced by $\mathrm{CsCl}$.

The results described above suggest, from the first assay, that the receptors can facilitate $\mathrm{Cl}^{-} / \mathrm{NO}_{3}{ }^{-}$exchange; the second assay, supports the hypothesis of $\mathrm{Cl}^{-} / \mathrm{HCO}_{3}{ }^{-}$antiport mechanism although in the first two minutes in the presence of sulfate for all the compounds except $\mathbf{L}^{\mathbf{4}}$ and $\mathbf{L}^{\mathbf{5}}$ a small amount of chloride efflux was observed. The caesium chloride assay demonstrates that for $\mathbf{L}^{2}, \mathbf{L}^{\mathbf{3}}, \mathbf{L}^{\mathbf{6}}-\mathbf{L}^{\mathbf{9}}$ the counter cation is involved in transport possibly via a $\mathrm{M}^{+} / \mathrm{Cl}^{-}$co-transport process.

We tested the $\mathrm{Cl}^{-} / \mathrm{NO}_{3}{ }^{-}$antiport activity of $\mathbf{L}^{2}-\mathbf{L}^{9}$ in vesicles composed of POPC-cholesterol $(7: 3)$. This mixture is a closer mimic of biological membranes than pure POPC lipid bilayers. The presence of cholesterol is known to increase the order in the bilayer and its viscosity. All the receptors tested showed a reduced rate of transport in the POPC-cholesterol system (see Fig. 7 for $\mathbf{L}^{2}$ and Fig. S58-S64 in ESI $\dagger$ for $\mathbf{L}^{3}-\mathbf{L}^{\mathbf{9}}$ ), providing evidence that for this class of receptor diffusion through the interior of the bilayer may be the rate determining step. ${ }^{31}$

To quantify the transport activity of compounds $\mathbf{L}^{2}-\mathbf{L}^{9}$ Hill analyses $^{32,33}$ for the chloride/nitrate and chloride/bicarbonate antiport assays were performed (see Fig. S14-S29, S31-S46 in ESI $\dagger$ ). Hill analysis allows the calculation of the $\mathrm{EC}_{50,270 \mathrm{~s}}$ which is a measure of transporter efficiency, defined as the required receptor concentration to mediate $50 \%$ of the total chloride efflux $270 \mathrm{~s}$ after the addition of the carrier (or after the bicarbonate 'pulse'). This allows us to compare the transport activity of the compounds. These values are summarised in Table 2, together with the Hill coefficients, which can be correlated to the number of transporter molecules required to transport a single anion and can provide further evidence for a mobile carrier mechanism. 


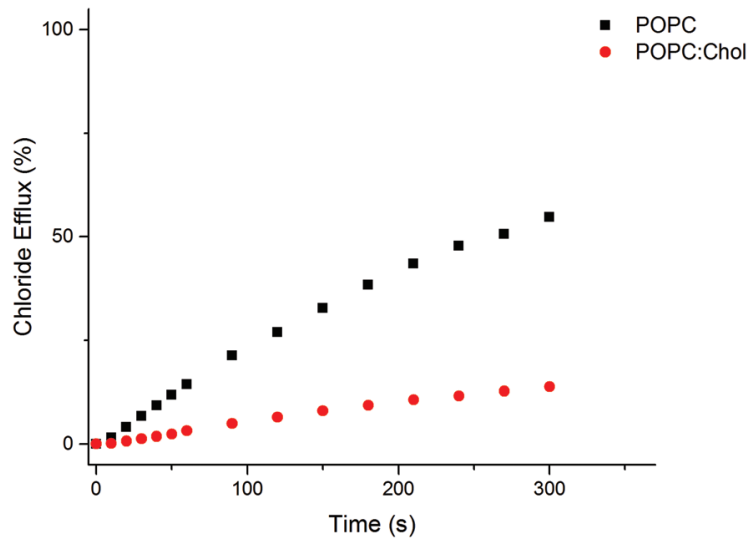

Fig. 7 Chloride efflux promoted by a DMSO solution of compound $\mathrm{L}^{2}$ (0.2 mol\% carrier to lipid) from unilamellar vesicles comprising of either POPC or POPC-cholesterol (7:3 molar ratio, POPC: Chol), loaded with $489 \mathrm{mM} \mathrm{NaCl}$ buffered to $\mathrm{pH} 7.2$ with $5 \mathrm{mM}$ sodium phosphate salts. The vesicles were dispersed in $489 \mathrm{mM} \mathrm{NaNO}_{3}$ buffered to $\mathrm{pH} 7.2$ with $5 \mathrm{mM}$ sodium phosphate salts. At the end of the experiment detergent was added to lyse the vesicles and calibrate the ISE to $100 \%$ chloride efflux. Each point represents an average of three trials. DMSO was used as a control.

Table 2 The $\mathrm{EC}_{50}$ is the concentration (mol\% carrier to lipid) needed to obtain $50 \%$ efflux after $270 \mathrm{~s}$ and $n$ is the Hill coefficient that represents an estimate of the number of transporter molecules required to transport a single anion

\begin{tabular}{lllll}
\hline Compound & $\begin{array}{l}\mathrm{EC}_{50} \text { at } 270 \mathrm{~s} \\
\left(\mathrm{Cl}^{-} / \mathrm{NO}_{3}{ }^{-}\right)\end{array}$ & $n$ & $\begin{array}{l}\mathrm{EC}_{50} \text { at } 270 \mathrm{~s} \\
\left(\mathrm{Cl}^{-} / \mathrm{HCO}_{3}^{-}\right)\end{array}$ & $n$ \\
\hline $\mathbf{L}^{\mathbf{2}}$ & 0.095 & 1.207 & 0.50 & 0.76 \\
$\mathbf{L}^{3}$ & 0.047 & 1.67 & 0.21 & 0.77 \\
$\mathbf{L}^{\mathbf{4}}$ & 0.039 & 1.07 & 0.14 & 0.98 \\
$\mathbf{L}^{\mathbf{5}}$ & 0.066 & 0.88 & 0.25 & 0.97 \\
$\mathbf{L}^{\mathbf{6}}$ & 0.10 & 1.39 & 0.76 & 0.80 \\
$\mathbf{L}^{\mathbf{7}}$ & 0.6 & 0.96 & 4.27 & 0.88 \\
$\mathbf{L}^{8}$ & 4.98 & 1.29 & 21.93 & 0.86 \\
$\mathbf{L}^{9}$ & 1.96 & 0.88 & 8.43 & 0.84 \\
& & & &
\end{tabular}

From the $\mathrm{EC}_{50,270 \mathrm{~s}}$ values reported in Table 2 the most active transporter among the series appears to be $\mathbf{L}^{\mathbf{4}}\left(\mathrm{EC}_{50,270 \mathrm{~s}}\right.$ $0.039 \mathrm{~mol} \%$ and $0.14 \mathrm{~mol} \%$ with respect to lipid for nitrate and bicarbonate antiport, respectively).

Further, Hill coefficients of $\sim 1$ provides further evidence that these compounds are functioning via a mobile carrier mechanism and are not forming membrane spanning channels in which we would expect the Hill coefficient to be higher.

\section{Conclusions}

In conclusion we have synthesised nine tris-urea receptors bearing a range of substituents attached to the pendant arms. We have studied the anion binding properties of the receptors both in solution and in the solid state and we have tested their ability to mediate chloride transport through membranes.
Solution studies demonstrate that these receptors bind anions with moderate stability constants (as reported in Table 1).

Solid state studies confirm the results observed in solution and indeed, despite many attempts, only three crystal structures were obtained. In particular, the crystal structure of $\mathbf{L}^{\mathbf{4}}$ in the presence of chloride suggests that the receptor has a good degree of pre-organization and binds chloride via the urea $\mathrm{NH}$ groups with a 1:2 stoichiometry. We also demonstrated that these systems are able to mediate transmembrane chloride transport as mobile carriers with different mechanisms, $\mathrm{Cl}^{-} / \mathrm{NO}_{3}{ }^{-}$and $\mathrm{Cl}^{-} / \mathrm{HCO}_{3}{ }^{-}$antiport, and metal-dependent cation co-transport. Hill-plot analysis demonstrates that the most active compound of the series is $\mathbf{L}^{\mathbf{4}}{ }^{34}$

\section{Acknowledgements}

CC would like to thank Fondazione Banco di Sardegna for financial support. PAG thanks the University of Southampton and the A*STAR ARAP programme for a studentship (SNB), the Royal Society and the Wolfson Foundation for a Research Merit Award and the EPSRC (EP/K039466/1) (Core Capability for Chemistry Research in Southampton). We also thank the EPSRC for access to the crystallographic facilities at the University of Southampton. ${ }^{35}$

\section{Notes and references}

1 F. M. Ashcroft, Ion Channels and Disease, Academic Press, San Diego, 2000.

2 P. A. Gale, R. Pérez-Tomás and R. Quesada, Acc. Chem. Res., 2013, 46, 2801-2813; N. Busschaert and P. A. Gale, Angew. Chem., Int. Ed., 2013, 52, 1374-1382.

3 S. Matile, A. Vargas Jentzsch, J. Montenegro and A. Fin, Chem. Soc. Rev., 2011, 40, 2453-2474.

4 (a) V. Soto-Cerrato, P. Manuel-Manresa, E. Hernando, S. Calabuig-Fariñas, A. Martínez-Romero, V. FernándezDueñas, K. Sahlholm, T. Knöpfel, M. García-Valverde, A. M. Rodilla, E. Jantus-Lewintre, R. Farràs, F. Ciruela, R. Pérez-Tomás and R. Quesada, J. Am. Chem. Soc., 2015, 137, 15892-15898; (b) S. N. Berry, V. Soto-Cerrato, E. N. W. Howe, H. J. Clarke, I. Mistry, A. Tavassoli, Y.-T. Chang, R. Pérez-Tomás and P. A. Gale, Chem. Sci., 2016, DOI: 10.1039/c6sc01643j; (c) W. Van Rossom, D. J. Asby, A. Tavassoli and P. A. Gale, Org. Biomol. Chem., 2016, 14, 2645-2650; (d) A. I. Share, K. Patel, C. Nativi, E. J. Cho, O. Francesconi, N. Busschaert, P. A. Gale, S. Roelens and J. L. Sessler, Chem. Commun., 2016, 52, 7560 .

5 S. J. Moore, C. J. E. Haynes, J. Gonzalez, J. L. Sutton, S. J. Brooks, M. E. Light, J. Herniman, G. J. Langley, V. Soto-Cerrato, R. Perez-Tomas, I. Marques, P. J. Costa, V. Felix and P. A. Gale, Chem. Sci., 2013, 4, 103-117.

6 L. E. Karagiannidis, C. J. E. Haynes, K. J. Holder, I. L. Kirby, S. J. Moore, N. J. Wells and P. A. Gale, Chem. Commun., 2014, 50, 12050-12053. 
7 P. B. Cranwell, J. R. Hiscock, C. J. E. Haynes, M. E. Light, N. J. Wells and P. A. Gale, Chem. Commun., 2013, 49, 874876.

8 N. Busschaert, P. A. Gale, C. J. E. Haynes, M. E. Light, S. J. Moore, C. C. Tong, J. T. Davis and J. W. A. Harrell, Chem. Commun., 2010, 46, 6252-6254.

9 N. Busschaert, L. E. Karagiannidis, M. Wenzel, C. J. E. Haynes, N. J. Wells, P. G. Young, D. Makuc, J. Plavec, K. A. Jolliffe and P. A. Gale, Chem. Sci., 2014, 5, 1118-1127.

10 N. Busschaert, M. Wenzel, M. E. Light, P. Iglesias-Hernández, R. Pérez-Tomás and P. A. Gale, J. Am. Chem. Soc., 2011, 133, 14136-14148.

11 B. Akhuli, I. Ravikumar and P. Ghosh, Chem. Sci., 2012, 3, 1522-1530.

12 P. Bose, R. Dutta and P. Ghosh, Org. Biomol. Chem., 2013, 11, 4581-4584.

13 R. Custelcean, Chem. Commun., 2013, 49, 2173-2182.

14 S. K. Dey, R. Chutia and G. Das, Inorg. Chem., 2012, 51, 1727-1738.

15 M. Emami Khansari, C. R. Johnson, I. Basaran, A. Nafis, J. Wang, J. Leszczynski and M. A. Hossain, RSC Adv., 2015, 5, 17606-17614.

16 Y. Hao, C. Jia, S. Li, X. Huang, X. J. Yang, C. Janiak and B. Wu, Supramol. Chem., 2012, 24, 88-94.

17 J. R. Hiscock, P. A. Gale and M. J. Hynes, Supramol. Chem., 2012, 24, 355-360.

18 M. Li, Y. Hao, B. Wu, C. Jia, X. Huang and X. J. Yang, Org. Biomol. Chem., 2011, 9, 5637-5640.

19 M. Li, B. Wu, C. Jia, X. Huang, Q. Zhao, S. Shao and X. J. Yang, Chem. - Eur. J., 2011, 17, 2272-2280.

20 M. Yamanaka, J. Inclusion Phenom. Macrocyclic Chem., 2013, $77,33-48$.
21 R. Dutta and P. Ghosh, Eur. J. Inorg. Chem., 2013, 26732681.

22 V. K. Bhardwaj, S. Sharma, N. Singh, M. S. Hundal and G. Hundal, Supramol. Chem., 2011, 23, 790-800.

23 W. Kim, S. K. Sahoo, G. D. Kim and H. J. Choi, Tetrahedron, 2015, 71, 8111-8116.

24 C. Jia, B. Wu, S. Li, Z. Yang, Q. Zhao, J. Liang, Q. S. Li and X. J. Yang, Chem. Commun., 2010, 46, 5376-5378.

25 R. Li, Y. Zhao, S. Li, P. Yang, X. Huang, X. J. Yang and B. Wu, Inorg. Chem., 2013, 52, 5851-5860.

26 Y. Zhang, R. Zhang, Y. Zhao, L. Ji, C. Jia and B. Wu, New J. Chem., 2013, 37, 2266-2270.

27 M. J. Hynes, J. Chem. Soc., Dalton Trans., 1993, 311-312.

28 B. D. Smith and T. N. Lambert, Chem. Commun., 2003, 2261-2268.

29 Y. Marcus, J. Chem. Soc., Faraday Trans., 1991, 87, 2995-2999.

30 X. Wu, L. W. Judd, E. N. W. Howe, A. M. Withecombe, V. Soto-Cerrato, H. Li, N. Busschaert, H. Valkenier, R. Perez-Tomas, D. N. Sheppard, Y.-B. Jiang, A. P. Davis and P. A. Gale, Chem, 2016, DOI: 10.1016/j.chempr.2016.04.002. 31 W. F. D. Bennett, J. L. MacCallum and D. P. Tieleman, J. Am. Chem. Soc., 2009, 131, 1972-1978.

32 A. V. Hill, Biochem. J., 1913, 7, 471.

33 S. Bhosale and S. Matile, Chirality, 2006, 18, 849-856.

34 N. Busschaert, S. J. Bradberry, M. Wenzel, C. J. E. Haynes, J. R. Hiscock, I. L. Kirby, L. E. Karagiannidis, S. J. Moore, N. J. Wells, J. Herniman, G. J. Langley, P. N. Horton, M. E. Light, I. Marques, P. J. Costa, V. Félix, J. G. Frey and P. A. Gale, Chem. Sci., 2013, 4, 3036-3045; N. J. Knight, E. Hernando, C. J. E. Haynes, N. Busschaert, H. J. Clarke, K. Takimoto, M. García-Valverde, J. G. Frey, R. Quesada and P. A. Gale, Chem. Sci., 2016, 7, 1600-1608.

35 S. J. Coles and P. A. Gale, Chem. Sci., 2012, 3, 683-689. 